Article

\title{
Production of New Antibacterial 4-Hydroxy- $\alpha$-Pyrones by a Marine Fungus Aspergillus niger Cultivated in Solid Medium
}

\author{
Lijian Ding ${ }^{1}{ }^{\oplus}$, Lu Ren $^{1}$, Shuang Li ${ }^{1}$, Jingjing Song ${ }^{1}$, Zhiwen Han ${ }^{1}$, Shan He ${ }^{1, *} \mathbb{C}$ and \\ Shihai $\mathrm{Xu}^{2, *}$ \\ 1 Li Dak Sum Yip Yio Chin Kenneth Li Marine Biopharmaceutical Research Center, \\ College of Food and Pharmaceutical Sciences, Ningbo University, Ningbo 315832, China; \\ dinglijian@nbu.edu.cn (L.D.); renlurenlu@163.com (L.R.); lishuang9892@163.com (S.L.); \\ 13123838771@163.com (J.S.); hanzhiwen1999@163.com (Z.H.) \\ 2 Department of Chemistry, College of Chemistry and Materials Science, Jinan University, \\ Guangzhou 510632, China \\ * Correspondence: heshan@nbu.edu.cn (S.H.); txush@jnu.edu.cn (S.X.); \\ Tel.: +86-574-8760-0458 (S.H.); +86-20-8522-1346 (S.X.)
}

Received: 17 May 2019; Accepted: 5 June 2019; Published: 10 June 2019

\begin{abstract}
Four 4-hydroxy- $\alpha$-pyrones including three new ones named nipyrones A-C (1-3) together with one known analogue germicidin C (4) were discovered from a marine sponge-derived fungus Aspergillus niger cultivated in a solid rice culture. Their structures and absolute configurations were elucidated through a combination of spectroscopic data and electronic circular dichroism (ECD) calculations as well as comparison with literature data. Compounds 1-4 were evaluated for their antibacterial activities against five pathogenic bacteria (Staphylococcus aureus, Escherichia coli, Bacillus subtilis, methicillin-resistant Staphylococcus aureus, and Mycobacterium tuberculosis). Compound 3 showed promising activity against $S$. aureus and B. subtilis, with minimum inhibitory concentration (MIC) values of $8 \mu \mathrm{g} / \mathrm{mL}$ and $16 \mu \mathrm{g} / \mathrm{mL}$, respectively, and displayed weak antitubercular activities against $M$. tuberculosis, with MIC value of $64 \mu \mathrm{g} / \mathrm{mL}$, while compounds 1 and 2 exhibited moderate antibacterial efficacy against four pathogenic bacteria with MIC values of 32-64 $\mu \mathrm{g} / \mathrm{mL}$.
\end{abstract}

Keywords: pyrone; sponge; marine fungi; ECD; antibacterial

\section{Introduction}

In recent years, sponge-derived fungi have represented a potential resource for discovery of novel bioactive molecules [1,2]. Numerous secondary metabolites with a broad spectrum of bioactivities have been isolated from sponge-derived fungi, inclusive of alkaloids [3], terpenoid [4], polyketides [5], and peptides [6]. $\alpha$-Pyrones are one of polyketide-biosynthetic skeletons, characterized by six-membered unsaturated cyclic scaffold containing a lactone [7]. $\alpha$-Pyrones can be widely found in the fungi and actinomycetes [8-10], and these molecules demonstrated a wide range of extraordinary biological activities, such as antimicrobial [11], anti-inflammatory [12], cytotoxic [13], and quorum sensing signaling molecules [14,15].

Members of the genus Aspergillus are well known to produce chemically diverse secondary metabolites, many of which have been developed to therapeutic leads for human health [16-19]. During our ongoing search for sponge-derived fungi capable of producing antibiotics, a sponge-derived fungus Aspergillus niger LS24 showed antimicrobial activities. HPLC-UV profile of crude extract of $A$. niger LS24 grown on solid rice medium indicated the presence of various $\alpha$-pyrone derivatives with the characteristic UV absorption similar to that of germicidin C [20]. Antibacterial-guided 
fractionation of the EtOAc extract from a scale-up culture led to the isolation and identification of three new 4-hydroxy- $\alpha$-pyrones, named nipyrones A-C (1-3) and one known analogue, germicidin $C$ (4) (Figure 1). Compounds 1-4 were evaluated for their antibacterial activities against five pathogenic bacteria. Herein, the isolation, structure elucidation, and antibacterial evaluation of these $\alpha$-pyrones are described.

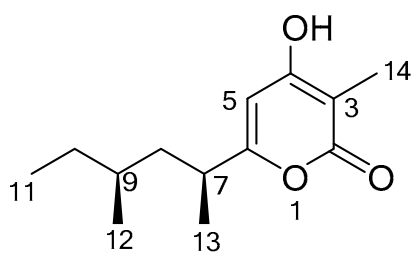

1<smiles>CCC(C)C[C@H](C)c1cc(OC)c(C)c(=O)o1</smiles>

3<smiles>CC[C@H](C)C[C@H](C)c1oc(=O)c(C)c(O)c1C</smiles>

2<smiles>CC[C@H](C)c1cc(O)c(C)c(=O)o1</smiles>

4

Figure 1. Structures of compounds 1-4.

\section{Results and Discussion}

\subsection{Structure Elucidation}

Nipyrone A (1) was obtained as a colorless oil. The molecular formula of $\mathbf{1}$ was assigned as $\mathrm{C}_{13} \mathrm{H}_{20} \mathrm{O}_{3}$ by HRESIMS data and gave an $[\mathrm{M}+\mathrm{H}]^{+}$peak at $m / z 225.1487$, suggesting four degrees of unsaturation. Its UV absorption at $290 \mathrm{~nm}$ indicated the presence of a conjugated $\alpha$-pyrone chromophore [21] (Figure S2). The ${ }^{1} \mathrm{H}-\mathrm{NMR}$ spectrum (Table 1) of $\mathbf{1}$ displayed one olefinic proton at $\delta_{\mathrm{H}} 6.16(\mathrm{~s}, \mathrm{H}-5)$, two methylenes at $\delta_{\mathrm{H}} 1.70(\mathrm{~m}, \mathrm{H}-8), 1.19(\mathrm{~m}, \mathrm{H}-8), 1.27(\mathrm{~m}, \mathrm{H}-10)$, and 1.10 $(\mathrm{m}, \mathrm{H}-10)$, two methines at $\delta_{\mathrm{H}} 2.64(\mathrm{~m}, \mathrm{H}-7)$ and $1.27(\mathrm{~m}, \mathrm{H}-9)$, two methyl doublets at $\delta_{\mathrm{H}} 0.84(\mathrm{~d}$, $\left.J=6.4 \mathrm{~Hz}, \mathrm{H}_{3}-12\right)$ and $1.19\left(\mathrm{~d}, J=6.9 \mathrm{~Hz}, \mathrm{H}_{3}-13\right)$, one methyl triplet at $\delta_{\mathrm{H}} 0.82\left(\mathrm{t}, J=7.3 \mathrm{~Hz}, \mathrm{H}_{3}-11\right)$, and one methyl singlet at $\delta_{\mathrm{H}} 1.97\left(\mathrm{~s}, \mathrm{H}_{3}-14\right)$. Analysis of ${ }^{13} \mathrm{C}$ NMR and DEPT spectra of 1 classified the 14 carbons into four methyls, two methylenes, three methines, and four nonprotonated carbons. HMBC correlations (Figure 2 ) of $\mathrm{H}_{3}-14 / \mathrm{C}-2\left(\delta_{\mathrm{C}} 167.3\right), \mathrm{C}-3\left(\delta_{\mathrm{C}} 98.7\right)$, and $\mathrm{C}-4\left(\delta_{\mathrm{C}} 168.7\right)$ as well as $\mathrm{H}-5 / \mathrm{C}-3\left(\delta_{\mathrm{C}} 98.7\right)$ in the HMBC spectrum suggested the existence of the 4-hydroxy-3-methyl $\alpha$-pyrone skeleton (Figure 2 and Figure S7). The structure of a 1,3-dimethylpentyl group was further verified by the COSY correlations $\left(\mathrm{H}-7 / \mathrm{H}_{2}-8 / \mathrm{H}_{3}-13, \mathrm{H}-9 / \mathrm{H}_{3}-12\right.$, and $\left.\mathrm{H}-10 / \mathrm{H}_{3}-11\right)$ and $\mathrm{HMBC}$ correlations from $\mathrm{H}_{3}-12 / \mathrm{H}_{3}-13$ to $\mathrm{C}-8\left(\delta_{\mathrm{C}} 41.7\right)$ and $\mathrm{H}_{3}-11$ to $\mathrm{C}-9\left(\delta_{\mathrm{C}} 32.1\right)$. The 1,3-dimethylpentyl group was connected to C-6 $\left(\delta_{C} 167.3\right)$ of 4-hydroxy-3-methyl $\alpha$-pyrone moiety, supported by the HMBC correlations of $\mathrm{H}-7 / \mathrm{C}-5\left(\delta_{\mathrm{C}} 100.0\right)$ and C-6 together with $\mathrm{H}_{3}-13 / \mathrm{C}-6$ (Figure 2). Thus, the planar structure of 1 was established as 4-hydroxy-3-methyl-6-(-4-methylhexan-2-yl)-2H-pyran-2-one. The relative configuration of 1 was established by the NOESY data (Figure S9). The NOE correlation between $\mathrm{H}_{3}-12 / \mathrm{H}_{3}-13$ clarified $\mathrm{H}_{3}-12$ and $\mathrm{H}_{3}-13$ to be cofacial of the side chain (Figure 2). Thus, the absolute configuration at C-7 and C-9 of $\mathbf{1}$ was identified as $7 S, 9 S$ or $7 R, 9 R$. The absolute configuration of $\mathbf{1}$ was further determined by comparing the experimental electronic circular dichroism (ECD) spectrum of 1 with the correspondingly time-dependent density functional theory (TDDFT)-calculated one. The Cotton effects of the experimental ECD spectrum of 1 matched very well with the calculated ECD spectrum for the model molecule of 7S,9S at the B3LYP/6-311 + G(d,p) level (Figure 3 and see Supplementary Materials), thus confirming its absolute configuration. 

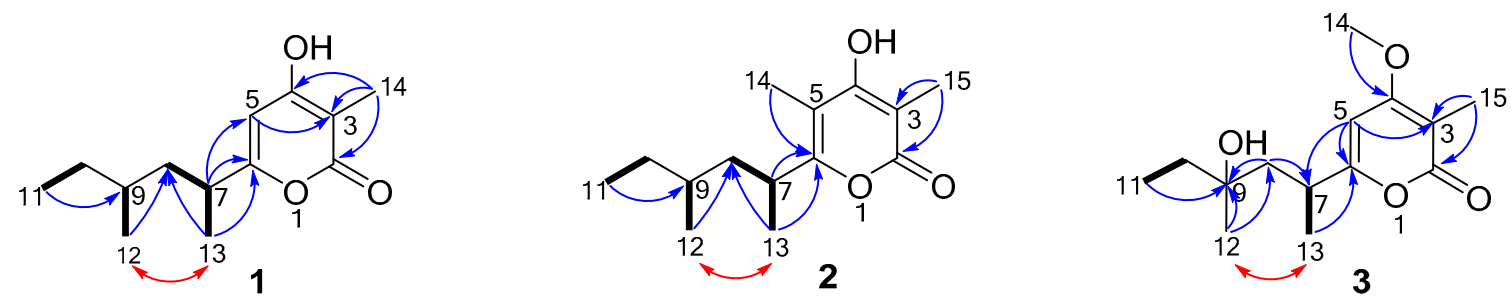

\section{$-\mathrm{COSY} \longrightarrow \mathrm{HMBC} \longleftrightarrow \mathrm{NOESY}$}

Figure 2. Key HMBC, COSY, and NOESY correlations of 1-3.

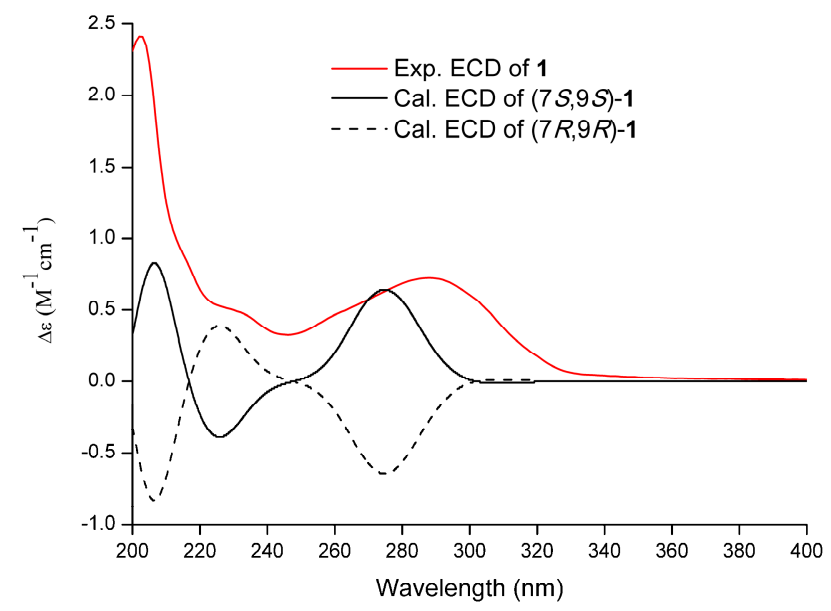

Figure 3. Experimental and calculated electronic circular dichroism (ECD) spectra of $\mathbf{1}$ in methanol.

Table 1. ${ }^{1} \mathrm{H}(600 \mathrm{MHz})$ and ${ }^{13} \mathrm{C}$ NMR $(150 \mathrm{MHz})$ data for compounds $1-3\left(\mathrm{CDCl}_{3}\right)$.

\begin{tabular}{|c|c|c|c|c|c|c|}
\hline \multirow{2}{*}{ No. } & \multicolumn{2}{|c|}{1} & \multicolumn{2}{|c|}{2} & \multicolumn{2}{|c|}{3} \\
\hline & $\delta_{C}$, Type & $\delta_{H}(J$ in $\mathrm{Hz})$ & $\delta_{C}$, Type & $\delta_{H}(J$ in $\mathrm{Hz})$ & $\delta_{C}$, Type & $\delta_{H}(J$ in $\mathrm{Hz})$ \\
\hline 2 & 167.3, C & - & $166.9, \mathrm{C}$ & - & $165.9, \mathrm{C}$ & - \\
\hline 3 & $98.7, \mathrm{C}$ & - & $98.2, \mathrm{C}$ & - & $100.8, \mathrm{C}$ & - \\
\hline 4 & $168.7, \mathrm{C}$ & - & $165.7, \mathrm{C}$ & - & 166.1, C & - \\
\hline 5 & $100.0, \mathrm{CH}$ & $6.16, \mathrm{~s}$ & $106.8, \mathrm{C}$ & - & $93.2, \mathrm{CH}$ & $6.04, \mathrm{~s}$ \\
\hline 6 & 167.3, C & - & $162.1, \mathrm{C}$ & - & 168.6, C & - \\
\hline 7 & $36.1, \mathrm{CH}$ & $2.64, \mathrm{~m}$ & $32.3, \mathrm{CH}$ & $3.00, \mathrm{~m}$ & $35.1, \mathrm{CH}$ & $2.85, \mathrm{~m}$ \\
\hline 8 & 41.7, $\mathrm{CH}_{2}$ & $1.70, \mathrm{~m} ; 1.19, \mathrm{~m}$ & $41.5, \mathrm{CH}_{2}$ & $1.79, \mathrm{~m} ; 1.19, \mathrm{~m}$ & $45.5, \mathrm{CH}_{2}$ & $\begin{array}{c}2.06, \mathrm{dd} \\
(14.7,5.8) \\
1.57, \mathrm{dd} \\
(14.6,4.3)\end{array}$ \\
\hline 9 & $32.1, \mathrm{CH}$ & $1.27, \mathrm{~m}$ & $32.4, \mathrm{CH}$ & $1.13, \mathrm{~m}$ & $72.9, \mathrm{C}$ & - \\
\hline 10 & 29.6, $\mathrm{CH}_{2}$ & $1.27, \mathrm{~m} ; 1.10, \mathrm{~m}$ & $29.9, \mathrm{CH}_{2}$ & $1.27, \mathrm{~m} ; 1.09, \mathrm{~m}$ & $35.3, \mathrm{CH}$ & $1.46, \mathrm{q}(7.5)$ \\
\hline 11 & $11.2, \mathrm{CH}_{3}$ & $0.82, \mathrm{t}(7.3)$ & $11.3, \mathrm{CH}_{3}$ & $0.81, \mathrm{t}(7.3)$ & $8.2, \mathrm{CH}_{3}$ & $0.88, \mathrm{t}(7.5)$ \\
\hline 12 & $19.2, \mathrm{CH}_{3}$ & $0.84, \mathrm{~d}(6.4)$ & $19.2, \mathrm{CH}_{3}$ & $0.83, \mathrm{~d}(6.2)$ & $25.9, \mathrm{CH}_{3}$ & $1.15, \mathrm{~s}$ \\
\hline 13 & $19.5, \mathrm{CH}_{3}$ & $1.19, \mathrm{~d}(6.9)$ & $19.3, \mathrm{CH}_{3}$ & $1.16, \mathrm{~d}(7.0)$ & $21.4, \mathrm{CH}_{3}$ & $1.29, \mathrm{~d}(7.0)$ \\
\hline 14 & $8.3, \mathrm{CH}_{3}$ & $1.97, \mathrm{~s}$ & $9.8, \mathrm{CH}_{3}$ & $2.00, \mathrm{~s}$ & $56.1, \mathrm{CH}_{3}$ & $3.87, \mathrm{~s}$ \\
\hline 15 & - & - & $8.8, \mathrm{CH}_{3}$ & $2.02, \mathrm{~s}$ & $8.5, \mathrm{CH}_{3}$ & $1.90, \mathrm{~s}$ \\
\hline
\end{tabular}

Nipyrone B (2) was also obtained as a colorless oil with a molecular formula of $\mathrm{C}_{14} \mathrm{H}_{22} \mathrm{O}_{3}$ as determined by HRESIMS data with one $\mathrm{CH}_{2}$ more than $\mathbf{1}$. The spectroscopic data of $\mathbf{2}$ (Table 1) were highly identical to that of 1 except for the absence of one olefinic proton and an additional methyl singlet. The additional methyl group was located at $C-5\left(\delta_{C} 106.8\right.$, Table 1$)$ by HMBC correlation from $\mathrm{H}_{3}-14$ to C-6 (Figure 2 and see Supplementary Materials). The absolute configuration of 2 tentatively led to deduction of the same as $\mathbf{1}$ based on the biosynthetic consideration and specific rotation. 
Nipyrone C (3) was isolated a as a colorless oil, and its molecular formula was assigned as $\mathrm{C}_{14} \mathrm{H}_{23} \mathrm{O}_{4}$ based on the HRESIMS ([M + H] $]^{+} \mathrm{m} / z$ 255.1591) and ${ }^{13} \mathrm{C}$ NMR data. The 1D and 2D NMR spectroscopic data for $\mathbf{3}$ (Table 1) closely resembled those of $\mathbf{1}$. Significant differences in the NMR data for 3 were only found in the resonances assigned to an additional hydroxy group and an additional methoxy group. Moreover, the C-9 position in $\mathbf{1}$ replaced by a hydroxy group in $\mathbf{3}$ was confirmed by chemical shift $C-9\left(\delta_{C} 72.9\right)$. The attachment of the methoxy group $\left(C-14, \delta_{C} 56.1\right)$ at $C-4$ was supported by the $\mathrm{HMBC}$ correlation of $\mathrm{H}_{3}-14 / \mathrm{C}-4$ (see Supplementary Materials). Based on the biosynthetic point of view and specific rotation, the absolute configuration of 3 might be assigned to be 7S, $9 R$.

In addition, compound 4 was identified as germicidin $C$ by comparison of its spectral data with those reported in [20]. Many $\alpha$-pyrone-based secondary metabolites biosynthesized by polyketide synthetase (PKS) pathway have been widely reported, uncovering their biosynthetic gene clusters $[7,22,23]$. We proposed that the polyketide chain primed with acetyl-CoA and malonyl-CoA was elongated, enolized, cyclized, methylated, hydroxylated, and released as the corresponding four 4-hydroxy- $\alpha$-pyrones. A probable biosynthesis pathway of $\mathbf{1 - 4}$ is illustrated in Scheme 1.

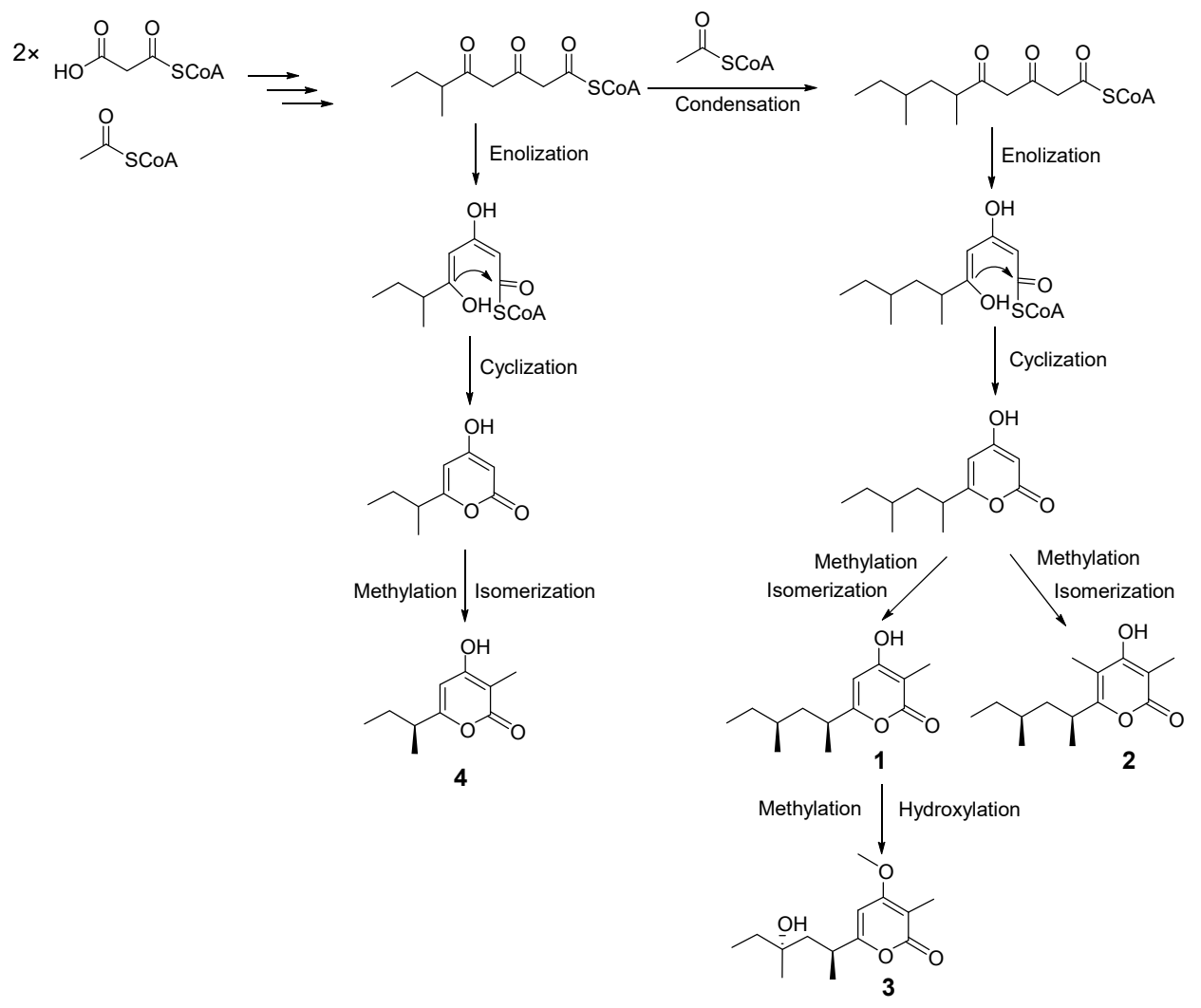

Scheme 1. Proposed biosynthetic pathway of 1-4.

\subsection{Biological Activities}

The antibacterial activities of 1-4 were evaluated against four bacteria, including Gram-positive and Gram-negative bacteria, using broth micro-dilution method within a concentration range of 256-1 $\mu \mathrm{g} / \mathrm{mL}$. Four pathogenic bacteria, including S. aureus, E. coli, B. subtilis, and methicillin-resistant $S$. aureus (MRSA) were performed. The results are shown in Table 2. Compound 3 exhibited significant inhibitory activity against $S$. aureus and B. subtilis, with minimum inhibitory concentration (MIC) values of 8 and $16 \mu \mathrm{g} / \mathrm{mL}$, respectively. Compounds 1, 2, and 4 exhibited moderate antimicrobial effect against S. aureus, E. coli, and B. subtilis, with MIC values in range of 32-64 $\mu \mathrm{g} / \mathrm{mL}$. Compounds 1-4 displayed weak antibiotic capacity against MRSA. Compound 3 possessed weak antitubercular activities against $M$. tuberculosis (MIC, $64 \mu \mathrm{g} / \mathrm{mL}$ ). 
Table 2. Antibacterial activities of compounds 1-4.

\begin{tabular}{cccccc}
\hline \multirow{2}{*}{ Compounds } & \multicolumn{5}{c}{ MIC $(\mu \mathrm{g} / \mathrm{mL})$} \\
\cline { 2 - 6 } & S. aureus & E. coli & B. subtilis & MRSA & M. tuberculosis \\
\hline 1 & 64 & 32 & 64 & 128 & 128 \\
2 & 64 & 64 & 64 & 128 & 128 \\
3 & 8 & 64 & 16 & 128 & 64 \\
4 & 64 & 64 & 32 & 128 & 128 \\
Chloramphenicol & 8 & 4 & 2 & 4 & - \\
Ethambutol & - & - & - & - & 8 \\
\hline
\end{tabular}

\section{Materials and Methods}

\subsection{General Experimental Procedures}

Optical rotations were determined with a P-2000 digital polarimeter (JASCO, Hachioji, Japan). UV spectra were obtained with a NADE Evolution 201 spectrophotometer (ThermoFisher, Waltham, MA, USA). IR spectra were measured on a Nicolet iS5 spectrometer (ThermoFisher, Waltham, MA, USA). NMR data were carried out at ambient temperature on a Varian $600 \mathrm{MHz}$ (Palo Alto, CA, USA) spectrometer operating at $600\left({ }^{1} \mathrm{H}\right)$ and $150\left({ }^{13} \mathrm{C}\right) \mathrm{MHz}$. HRESIMS data were recorded on an Agilent Technologies 6520 Accurate Mass Q-TOF LC/MS spectrometer equipped with an ESI source (Agilent Technologies, Santa Clara, CA, USA). Medium-pressure liquid chromatography (MPLC) was performed on a FLEXA Purification System (Bonna-Agela Technologies Co., Tianjin, China) using a $15 \mu \mathrm{m}$ ODS column (Santai Technologies, Inc., Changzhou, China). Semi-preparative HPLC was performed on an YMC-Pack Pro C18 RS column $(5 \mu \mathrm{m}, 250 \times 10 \mathrm{~mm}$ id; YMC, Kyoto, Japan) with a Waters 600 separation system coupled with a Waters 2998 Photodiode Array detector (Waters, MA, USA). Column chromatography (CC) was performed on silica gel (200-300 mesh, Qingdao Haiyang Chemical Factory, Qingdao, China) and Sephadex LH-20 (25-100 m; Pharmacia, Uppsala, Sweden).

\subsection{Fungal Material}

Marine sponge Haliclona sp. was collected at Lingshui, Hainan Province, China. The sponge tissue was cut into small pieces of about $0.1 \mathrm{~cm}^{3}$ each, which were homogenized with sterile seawater. $20 \mu \mathrm{L}$ of the diluted homogenate (1:100, sterile seawater) was inoculated in PDA agar plates, which were incubated for periods of 3 days to 4 weeks for purifying fungal colonies. 15 fungal isolates were obtained. Among them, the EtOAc extract of the fungal strain LS24 showed antimicrobial activities. Surprisingly, its extract showed stronger antimicrobial effects (MICs, 32-128 $\mu \mathrm{g} / \mathrm{mL}$ against different pathogenic bacteria) when grown on solid rice medium in comparison to liquid medium (MICs, $>128 \mu \mathrm{g} / \mathrm{mL}$ against different pathogenic bacteria). The fungal strain LS24 was identified using morphological studies, DNA amplification, and the internal transcribed spacer region (ITS) sequencing (GenBank accession ID: KX290301, 100\% similarity). The isolate was stored on PDA medium (potato $200 \mathrm{~g}$, dextrose $20 \mathrm{~g}$, sea salt $35 \mathrm{~g}$ and agar $15 \mathrm{~g}$ in $1.0 \mathrm{~L}$ of $\mathrm{H}_{2} \mathrm{O}, \mathrm{pH}$ 7.4-7.8) slants at $4{ }^{\circ} \mathrm{C}$. A voucher strain was preserved at College of Food and Pharmaceutical Sciences, Ningbo University, Ningbo, China.

\subsection{Fermentation}

The fungus $A$. niger was cultured on PDA agar plate at $28^{\circ} \mathrm{C}$ for 7 days. The fungal colony was further inoculated into the PDB medium (potato $200 \mathrm{~g}$, dextrose $20 \mathrm{~g}$, and sea salt $35 \mathrm{~g}$ in $1.0 \mathrm{~L}$ of $\mathrm{H}_{2} \mathrm{O}$, $\mathrm{pH}$ 7.4-7.8) at $28^{\circ} \mathrm{C}$ for 3 days on a rotating shaker (180 rpm). Then, a large-scale fermentation of the strain was performed. The fungal seed broth $(20 \mathrm{~mL})$ was added to 10 flasks $(1000 \mathrm{~mL})$, each containing $100 \mathrm{~g}$ rice and $160 \mathrm{~mL}$ water. These flasks were incubated at $28^{\circ} \mathrm{C}$ for 30 days under static conditions. 


\subsection{Extraction and Isolation}

All the fermented materials were extracted with $5 \mathrm{~L}$ EtOAc three times to afford a brown extract $(8 \mathrm{~g})$. The EtOAc extract was subjected to vacuum liquid chromatography (VLC) on a silica gel column ( $6 \times 15 \mathrm{~cm}, 200-300 \mathrm{mesh}$ ) using step gradient elution with petroleum ether/EtOAc (from 20:1 to 0:1, v/v) to obtain seven fractions (Fr.1-7) according to HPLC analysis. Fraction 4 was further chromatographed over a Sephadex LH-20 column, eluted with $\mathrm{CH}_{3} \mathrm{OH}$ and $\mathrm{CH}_{2} \mathrm{Cl}_{2}(1: 1, v / v)$, yielding three subfractions (Fr.4.A-C). Fr.4.B (300 mg) was further separated into six subfractions (Fr.4.B.1-6) by ODS silica gel MPLC eluting with $\mathrm{MeOH} / \mathrm{H}_{2} \mathrm{O}(30-100 \%, 120 \mathrm{~min}$, flow rate $20 \mathrm{~mL} / \mathrm{min})$ to obtain nine subfractions (Fr.4.B.1-9). Fr.4.B.3 was separated by semipreparative HPLC $\left(35 \% \mathrm{MeCN} / \mathrm{H}_{2} \mathrm{O}, 2 \mathrm{~mL} / \mathrm{min}\right.$, detected at $290 \mathrm{~nm})$ to provide $1\left(1.3 \mathrm{mg}, t_{\mathrm{R}} 32 \mathrm{~min}\right)$ and $\mathbf{2}\left(1.2 \mathrm{mg}, t_{\mathrm{R}} 34 \mathrm{~min}\right)$. Meanwhile, Fr.4.B.7 was purified by semipreparative $\mathrm{HPLC}\left(40 \% \mathrm{MeCN} / \mathrm{H}_{2} \mathrm{O}, 2 \mathrm{~mL} / \mathrm{min}\right.$, detected at $\left.290 \mathrm{~nm}\right)$ to yield $3\left(1.1 \mathrm{mg}, t_{\mathrm{R}} 30 \mathrm{~min}\right)$ and 4 ( $\left.3.1 \mathrm{mg}, t_{\mathrm{R}} 32 \mathrm{~min}\right)$.

Nipyrone A (1): colorless oil; $[\alpha]_{D}^{25}+43$ (c 0.23, MeOH); CD $\lambda_{\max }(\Delta \varepsilon) 203(+2.41), 288(+0.72) \mathrm{nm}$; UV $(\mathrm{MeOH})(\log \varepsilon) \lambda_{\max } 290(4.19) \mathrm{nm} ; \mathrm{IR}(\mathrm{KBr}) v_{\max } 3093,2964,2930,2876,2680,1662,1582,1459,1415$, 1375, 1245, 1152, 1126, 1057, 972, 932, 876, 837, 760, $705 \mathrm{~cm}^{-1} ;{ }^{1} \mathrm{H}$ and ${ }^{13} \mathrm{C}$ NMR data, see Table 1; HRESIMS $m / z 225.1487[\mathrm{M}+\mathrm{H}]^{+}$(calcd for $\mathrm{C}_{13} \mathrm{H}_{21} \mathrm{O}_{3}, 225.1485$ ).

Nipyrone B (2): colorless oil; $[\alpha]_{D}^{25}+72$ (c 1.13, MeOH); UV (MeOH) (log $\left.\varepsilon\right) \lambda_{\max } 286$ (3.86) nm; IR (KBr) $v_{\max } 3219,2963,2930,2875,1705,1671,1606,1568,1459,1408,1377,1232,1156,1093,1035,958,873,806$, $761 \mathrm{~cm}^{-1} ;{ }^{1} \mathrm{H}$ and ${ }^{13} \mathrm{C}$ NMR data, see Table 1 ; HRESIMS m/z $239.1639[\mathrm{M}+\mathrm{H}]^{+}$(calcd for $\mathrm{C}_{14} \mathrm{H}_{23} \mathrm{O}_{3}$, 239.1628).

Nipyrone C (3): colorless oil; $[\alpha]_{D}^{25}+35$ (c 0.12, MeOH); UV (MeOH) (log $\left.\varepsilon\right) \lambda_{\max } 299$ (3.92) nm; IR (KBr) $v_{\max } 3429,3101,2967,2929,2876,1686,1642,1566,1462,1406,1380,1325,1251,1192,1141,1099,1032$, $968,941,905,804,756 \mathrm{~cm}^{-1} ;{ }^{1} \mathrm{H}$ and ${ }^{13} \mathrm{C}$ NMR data, see Table 1 ; HRESIMS $m / z 255.1591[\mathrm{M}+\mathrm{H}]^{+}$(calcd for $\left.\mathrm{C}_{14} \mathrm{H}_{23} \mathrm{O}_{4}, 255.1591\right)$.

\subsection{Antibacterial Assay}

The antibacterial effects of compounds 1-4 were evaluated against Gram-positive bacteria $S$. aureus ATCC 25923, B. subtilis ATCC 6633, methicillin-resistant S. aureus ATCC 43300 (MRSA), and Gram-negative bacterium E. coli ATCC 25922 according to a previously described method [24]. The test compounds were dissolved in DMSO $(1 \mathrm{mg} / \mathrm{mL}$ for $1-4)$. The minimum inhibitory concentration (MIC) values were defined as the lowest concentration of test compound that inhibited the growth of more than $99 \%$ of the bacterial population after overnight incubation in 96-well microtiter plates, as detected by eye. Briefly, $100 \mu \mathrm{L}$ of each bacterial solution was inoculated in each well $\left(10^{5} \mathrm{CFU} / \mathrm{mL}\right)$ and added with $100 \mu \mathrm{L}$ of each compound solution and control in triples. Microplates were incubated for $24 \mathrm{~h}$ at $37^{\circ} \mathrm{C}$. The final concentrations of each test compound in the wells were in the range of 256-1 $\mu \mathrm{g} / \mathrm{mL}$ using sequential 2-fold serial dilutions. The final DMSO concentration was maintained at $0.5 \%$ by adding the medium. Chloramphenicol and DMSO were used as the positive control and the negative control, respectively. The detailed method of the antitubercular activity of compounds 1-4 against $M$. tuberculosis $\mathrm{H} 37 \mathrm{Rv}$ was described by the agar proportion method based on the previous report [25]. The blank control was DMSO. Ethambutol was used as a positive control.

\section{Conclusions}

In summary, three new 4-hydroxy- $\alpha$-pyrone derivatives, nipyrones A-C (1-3) along with one known analogue germicidin $C(4)$ were isolated from a marine sponge-derived fungus $A$. niger grown on a solid rice culture. These 4 -hydroxy- $\alpha$-pyrone derivatives have in common the differences in functional group substitution and side chain length. Biogenetically, nipyrones A-C (1-3) are presumably originated from the polyketide pathway. This study further expanded the structural diversity of naturally occurring $\alpha$-pyrone derivatives. Notably, compound 3 displayed significant inhibitory 
effects on two pathogenic bacteria, S. aureus and E. coli and may be considered to have potential as an antibiotic agent.

Supplementary Materials: The following are available online at http://www.mdpi.com/1660-3397/17/6/344/s1. HRESIMS, NMR, IR, UV of the new compounds 1-3; ECD calculation data for 1.

Author Contributions: S.H. and S.X. conceived and designed the experiments. L.D., L.R. and Z.H. performed the experiments. L.D., L.R., S.L., J.S., and S.H. analyzed the data. L.D. and S.H. wrote the paper.

Funding: This study was supported by the National Key Research and Development Program of China (2018YFC0310900), the National Natural Science Foundation of China (41776168, 41706167, 21672084, 41876145), Ningbo Public Service Platform for High-Value Utilization of Marine Biological Resources (NBHY-2017-P2), the National 111 Project of China (D16013), the Li Dak Sum Yip Yio Chin Kenneth Li Marine Biopharmaceutical Development Fund, and the K.C. Wong Magna Fund in Ningbo University.

Conflicts of Interest: The authors declare no conflict of interest.

\section{References}

1. Gu, B.B.; Wu, Y.; Tang, J.; Jiao, W.H.; Li, L.; Sun, F.; Wang, S.P.; Yang, F.; Lin, H.W. Azaphilone and isocoumarin derivatives from the sponge-derived fungus Eupenicillium sp. 6A-9. Tetrahedron Lett. 2018, 59, 3345-3348. [CrossRef]

2. Tian, Y.; Lin, X.; Zhou, X.; Liu, Y. Phenol derivatives from the sponge-derived fungus Didymellaceae sp. SCSIO F46. Front. Chem. 2018, 6, 536. [CrossRef] [PubMed]

3. Buttachon, S.; Ramos, A.A.; Inacio, A.; Dethoup, T.; Gales, L.; Lee, M.; Costa, P.M.; Silva, A.M.S.; Sekeroglu, N.; Rocha, E.; et al. Bis-indolyl benzenoids, hydroxypyrrolidine derivatives and other constituents from cultures of the marine sponge-associated fungus Aspergillus candidus KUFA0062. Mar. Drugs 2018, 16, 119. [CrossRef] [PubMed]

4. Yong, L.; Dong, L.; Cheng, Z.; Proksch, P.; Lin, W. Cytotoxic trichothecene-type sesquiterpenes from the sponge-derived fungus Stachybotrys chartarum with tyrosine kinase inhibition. RSC Adv. 2017, 7, 7259-7267.

5. Tian, Y.Q.; Lin, S.T.; Kumaravel, K.; Zhou, H.; Wang, S.Y.; Liu, Y.H. Polyketide-derived metabolites from the sponge-derived fungus Aspergillus sp. F40. Phytochem. Lett. 2018, 27, 74-77. [CrossRef]

6. Ding, L.J.; Yuan, W.; Liao, X.J.; Han, B.N.; Wang, S.P.; Li, Z.Y.; Xu, S.H.; Zhang, W.; Lin, H.W. Oryzamides A-E, cyclodepsipeptides from the sponge-derived fungus Nigrospora oryzae PF18. J. Nat. Prod. 2016, 79, 2045-2052. [CrossRef]

7. Schäberle, T.F. Biosynthesis of $\alpha$-pyrones. Beilstein J. Org. Chem. 2016, 12, 571-588. [CrossRef]

8. Liu, D.; Li, X.M.; Meng, L.; Li, C.S.; Gao, S.S.; Shang, Z.; Proksch, P.; Huang, C.G.; Wang, B.G. Nigerapyrones A-H, $\alpha$-pyrone derivatives from the marine mangrove-derived endophytic fungus Aspergillus niger MA-132. J. Nat. Prod. 2011, 74, 1787-1791. [CrossRef]

9. Ma, Y.M.; Li, T.; Ma, C.C. A new pyrone derivative from an endophytic Aspergillus tubingensis of Lycium ruthenicum. Nat. Prod. Res. 2016, 30, 1499-1503. [CrossRef]

10. Rab, E.; Kekos, D.; Roussis, V.; Ioannou, E. $\alpha$-pyrone polyketides from Streptomyces ambofaciens BI0048, an endophytic actinobacterial strain isolated from the red alga Laurencia glandulifera. Mar. Drugs 2017, 15, 389. [CrossRef]

11. Zhang, H.; Saurav, K.; Yu, Z.; Mándi, A.; Kurtán, T.; Li, J.; Tian, X.; Zhang, Q.; Zhang, W.; Zhang, C. $\alpha$-Pyrones with diverse hydroxy substitutions from three marine-derived Nocardiopsis strains. J. Nat. Prod. 2016, 79, 1610-1618. [CrossRef] [PubMed]

12. Lee, J.; Han, C.; Lee, T.G.; Chin, J.; Choi, H.; Lee, W.; Paik, M.J.; Won, D.H.; Jeong, G.; Ko, J. Marinopyrones A-D, $\alpha$-pyrones from marine-derived actinomycetes of the family Nocardiopsaceae. Tetrahedron Lett. 2016, 57, 1997-2000. [CrossRef]

13. Li, J.; Wu, X.; Ding, G.; Feng, Y.; Jiang, X.; Guo, L.; Che, Y. $\alpha$-Pyrones and pyranes from the plant pathogenic fungus Pestalotiopsis scirpina. Eur. J. Org. Chem. 2012, 2012, 2445-2452. [CrossRef]

14. Brachmann, A.O.; Brameyer, S.; Kresovic, D.; Hitkova, I.; Kopp, Y.; Manske, C.; Schubert, K.; Bode, H.B.; Heermann, R. Pyrones as bacterial signaling molecules. Nat. Chem. Biol. 2013, 9, 573-578. [CrossRef] [PubMed]

15. Fu, P.; Liu, P.; Gong, Q.; Wang, Y.; Wang, P.; Zhu, W. $\alpha$-Pyrones from the marine-derived actinomycete Nocardiopsis dassonvillei subsp. dassonvillei XG-8-1. RSA Adv. 2013, 3, 20726-20731. [CrossRef] 
16. Nakamura, I.; Kanasaki, R.; Yoshikawa, K.; Furukawa, S.; Fujie, A.; Hamamoto, H.; Sekimizu, K. Discovery of a new antifungal agent ASP2397 using a silkworm model of Aspergillus fumigatus infection. J. Antibiot. 2017, 70, 41-44. [CrossRef]

17. Wang, C.; Guo, L.; Hao, J.; Wang, L.; Zhu, W. $\alpha$-Glucosidase inhibitors from the marine-derived fungus Aspergillus flavipes HN4-13. J. Nat. Prod. 2016, 79, 2977-2981. [CrossRef]

18. Zhu, H.; Chen, C.; Tong, Q.; Yang, J.; Wei, G.; Xue, Y.; Wang, J.; Luo, Z.; Zhang, Y. Asperflavipine A: A cytochalasan heterotetramer uniquely defined by a highly complex tetradecacyclic ring system from Aspergillus flavipes QCS12. Angew. Chem. Int. Ed. 2017, 56, 5242-5246. [CrossRef]

19. Zhang, X.; Li, Z.; Gao, J. Chemistry and biology of secondary metabolites from Aspergillus genus. Nat. Prod. J. 2018, 8, 275-304. [CrossRef]

20. Aoki, Y.; Matsumoto, D.; Kawaide, H.; Natsume, M. Physiological role of germicidins in spore germination and hyphal elongation in Streptomyces coelicolor A3(2). J. Antibiot. 2011, 64, 607-611. [CrossRef]

21. Barrero, A.F.; Oltra, J.E.; Herrador, M.M.; Cabrera, E.; Sanchez, J.F.; Quílez, J.F.; Rojas, F.J.; Reyes, J.F. Gibepyrones: $\alpha$-pyrones from Gibberella fujikuroi. Tetrahedron 1993, 49, 141-150. [CrossRef]

22. Kasahara, K.; Fujii, I.; Oikawa, H.; Ebizuka, Y. Expression of Alternaria solani PKSF generates a set of complex reduced-type polyketides with different carbon-lengths and cyclization. Chembiochem 2010, 7, 920-924. [CrossRef] [PubMed]

23. Xu, W.; Cai, X.; Jung, M.E.; Tang, Y. Analysis of intact and dissected fungal polyketide synthase-nonribosomal peptide synthetase in vitro and in Saccharomyces cerevisiae. J. Am. Chem. Soc. 2010, 132, 13604-13607. [CrossRef] [PubMed]

24. An, C.-L.; Kong, F.-D.; Ma, Q.-Y.; Xie, Q.-Y.; Yuan, J.-Z.; Zhou, L.-M.; Dai, H.-F.; Yu, Z.-F.; Zhao, Y.-X. Chemical constituents of the marine-derived fungus Aspergillus sp. SCS-KFD66. Mar. Drugs 2018, 16, 468. [CrossRef]

25. Braña, A.F.; Sarmiento-Vizcaíno, A.; Pérez-Victoria, I.; Martín, J.; Otero, L.; Palacios-Gutiérrez, J.J.; Fernández, J.; Mohamedi, Y.; Fontanil, T.; Salmón, M.; et al. Desertomycin G, a new antibiotic with activity against Mycobacterium tuberculosis and human breast tumor cell lines produced by Streptomyces althioticus MSM3, isolated from the Cantabrian Sea Intertidal macroalgae Ulva sp. Mar. Drugs 2019, 17, 114. [CrossRef] [PubMed]

(C) 2019 by the authors. Licensee MDPI, Basel, Switzerland. This article is an open access article distributed under the terms and conditions of the Creative Commons Attribution (CC BY) license (http://creativecommons.org/licenses/by/4.0/). 